University of Nebraska - Lincoln

DigitalCommons@University of Nebraska - Lincoln

\title{
Eolian Additions to Late Quaternary Alpine Soils, Indian Peaks Wilderness Area, Colorado Front Range
}

Daniel R. Muhs

U.S. Geological Survey, dmuhs@usgs.gov

James B. Benedict

Center for Mountain Archeology

Follow this and additional works at: https://digitalcommons.unl.edu/usgsstaffpub

Part of the Earth Sciences Commons

Muhs, Daniel R. and Benedict, James B., "Eolian Additions to Late Quaternary Alpine Soils, Indian Peaks Wilderness Area, Colorado Front Range" (2006). USGS Staff -- Published Research. 150.

https://digitalcommons.unl.edu/usgsstaffpub/150

This Article is brought to you for free and open access by the US Geological Survey at DigitalCommons@University of Nebraska - Lincoln. It has been accepted for inclusion in USGS Staff -- Published Research by an authorized administrator of DigitalCommons@University of Nebraska - Lincoln. 


\section{Eolian Additions to Late Quaternary Alpine Soils, Indian Peaks Wilderness Area, Colorado Front Range}

\author{
Daniel R. Muhs* and \\ James B. Benedict $\dagger$ \\ *U.S. Geological Survey, \\ MS 980, Box 25046, Federal Center, \\ Denver, Colorado 80225, U.S.A. \\ dmuhs@usgs.gov \\ $\dagger$ Center for Mountain Archeology, \\ 8297 Overland Road, Ward, \\ Colorado 80481, U.S.A.
}

\begin{abstract}
Surface horizons of many alpine soils on Quaternary deposits in high-mountain settings are enriched in silt. The origin of these particles has been debated, particularly in the Rocky Mountain region of North America. The most common explanations are frost shattering of coarser particles and eolian additions from distant sources. We studied soil A horizons on alpine moraines of late-glacial (Satanta Peak) age in the Colorado Front Range. Surface horizons of soils on these moraines are enriched in silt and have a particle size distribution that resembles loess and dust deposits found elsewhere. The compositions of sand and silt fractions of the soils were compared to possible local source rocks, using immobile trace elements $\mathrm{Ti}, \mathrm{Nb}, \mathrm{Zr}, \mathrm{Ce}$, and $\mathrm{Y}$. The sand fractions of soils have a wide range of trace element ratios, similar to the range of values in the local biotite gneiss bedrock. In contrast, silt fractions have narrower ranges of trace element ratios that do not overlap the range of these ratios in biotite gneiss. The particle size and geochemical results support an interpretation that silts in these soils are derived from airborne dust. Eolian silts were most likely derived from distant sources, such as the semiarid North Park and Middle Park basins to the west. We hypothesize that much of the eolian influx to soils of the Front Range occurred during an early to mid-Holocene warm period, when sediment availability in semiarid source basins was at a maximum.
\end{abstract}

\section{Introduction}

Silt-enriched A horizons of alpine tundra soils have been reported from many of the world's high-mountain environments, including Europe (Küfmann, 2003), Asia (Lehmkuhl et al., 2000; Rost, 2001; Bäumler, 2001), Africa (Zeuner, 1949), and Canada (Sneddon et al., 1972). In the United States, detailed studies have been made of silt-rich surface horizons in alpine soils, particularly in the Rocky Mountain region of Colorado, Wyoming, and Utah (Benedict, 1973, 1981; Shroba and Birkeland, 1983; Birkeland et al., 1987; Litaor, 1987; Munn and Spackman, 1990; Dahms, 1993; Hall and Shroba, 1993; Bockheim and Koerner, 1997). These studies have reported that many alpine soil A horizons have silt contents of $30-60 \%$, whereas $\mathrm{C}$ horizons in the same soils have silt contents of $20 \%$ or less and are often $10 \%$ or less.

The origin of silt enrichments in the surface horizons of alpine soils has been hotly debated. Several workers have proposed that silts in alpine soils result from frost shattering of coarser particles (Zeuner, 1949; Rieger, 1983; Munn, 1988, 1992; Munn and Spackman, 1990). Although laboratory experiments by Lautridou and Ozouf (1982), Wright et al. (1998), and Wright (2001) show that frost shattering can produce silt-sized particles from coarser particles, the amount of fine particle production is small compared to other processes, such as glacial grinding or fluvial comminution. In the alpine environment of the Colorado Front Range, detailed field measurements by Thorn (1979) have shown that those settings with adequate moisture lack sufficient freezing intensity for frost shattering and those sites with appropriate temperature regimes lack moisture.

Other investigators have favored an eolian origin for silt enrichments in alpine soils. Benedict (1973, 1981, 2000), Shroba and Birkeland (1983), Birkeland et al. (1987, 2003), Litaor (1987, 1988), Dixon (1991), Dahms (1992, 1993), Hall and Shroba (1993), and Bockheim and Koerner (1997) all attributed silt enrichments in surface horizons of alpine soils to eolian influx. Modern dust fall has also been documented in alpine regions. Dahms and Rawlins (1996) reported abundant silt collected in dust traps over a two-year period in the Wind River Mountains of Wyoming. Thorn and Darmody (1980, 1985) reported that silt was abundant in modern alpine snowpatches of the Colorado Front Range, in landscape positions where the only possible sediment input is eolian.

The origin of silt-sized particles in alpine soils is an important issue, because silt and clay enrichments have a significant effect on the mineralogy, chemistry, nutrient status, and moisture-holding capacity of soils. Soil A horizons are the main media for plant growth in the environmentally sensitive alpine biome. Indeed, Shaver and Chapin (1986), Bowman et al. (1993), and Theodose and Bowman (1997) have pointed out that both Arctic (Alaska) and alpine (Colorado) tundra communities are, in part, nutrient limited. Addition of fine-grained particles (silts and clays) increases both the nutrient content and nutrient-holding ability of soils. Furthermore, the moisture-holding capacity of coarse-grained (gravelly or sandy) tundra soils derived from talus or till is much lower than similar soils with abundant quantities of silt. Thus, much of the nutrient- and moisture-holding capacity of tundra soils may be a function of the silt and clay content. In this study, we evaluate the possible origins of silt enrichments in surface horizons of alpine tundra and tundra-forest ecotone soils in the Indian Peaks Wilderness Area of the Colorado Front Range.

\section{Indian Peaks Wilderness Area}

The Indian Peaks Wilderness Area (Figs. 1-3) is situated in Arapaho and Roosevelt National Forests of the Colorado Front Range. The area occupies tundra, tundra-forest ecotone, and parts of subalpine forest on both sides of the Continental Divide. Pearson (1980) mapped the bedrock geology in the region, and Young (1991) produced a detailed geologic map for part of the area. The rocks that are the most 

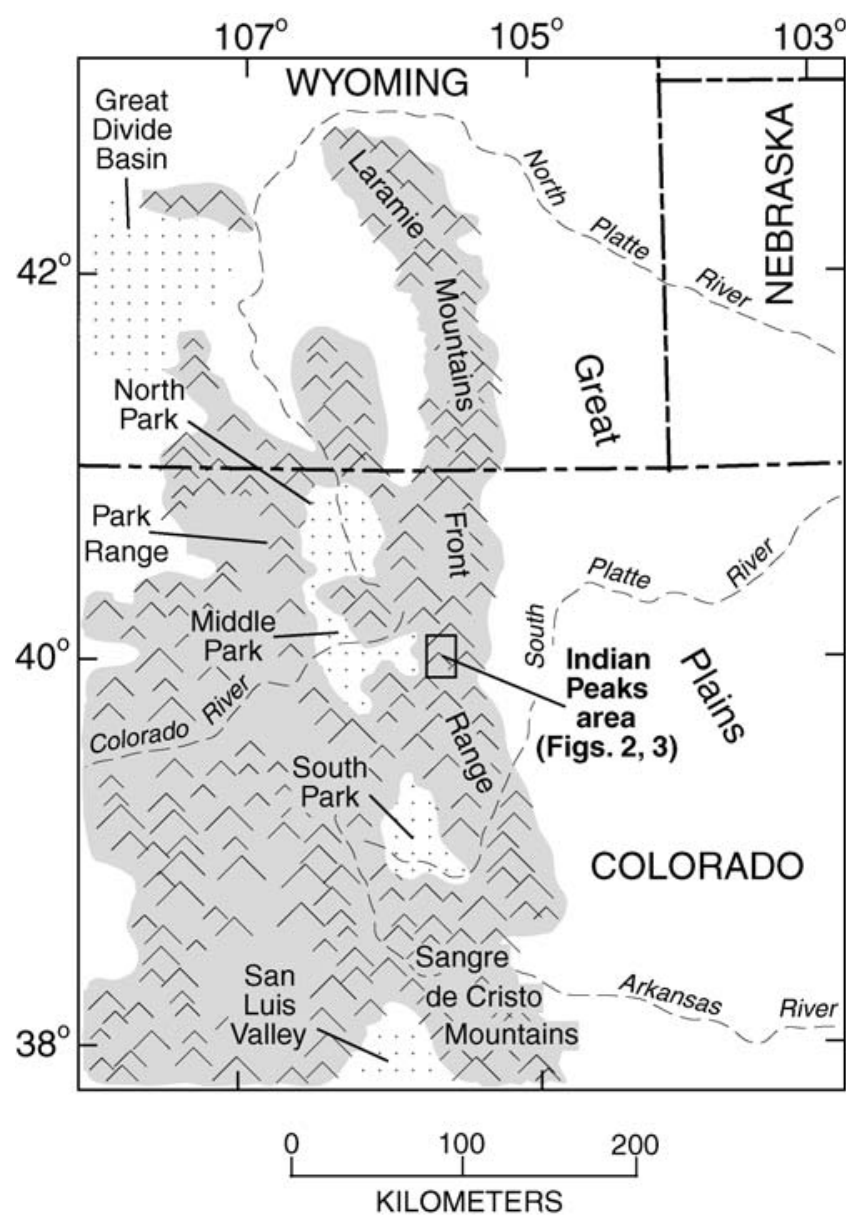

FIGURE 1. Map of north-central Colorado and parts of adjacent states, showing mountain ranges, semiarid steppe basins in intermountain areas, major rivers, and location of the Indian Peaks Wilderness Area.

extensive are the Silver Plume Granite, Boulder Creek Granodiorite, and biotite gneiss, all of Precambrian age. In the specific areas we studied, the main rocks are biotite gneiss with smaller amounts of Boulder Creek granodiorite and Silver Plume granite (Fig. 3).

Quaternary deposits mantle much of the area and consist of till, outwash, alluvium, talus, and rock glacier deposits. The late Quaternary stratigraphy of the area has been the focus of study for several decades, with an emphasis on glacial history. The most extensive ice advance during the late Quaternary was the Pinedale glaciation, which left thick deposits of till in many valleys of the Front Range (Madole et al., 1998). The Pinedale glaciation may have begun around $\sim 30,000{ }^{14} \mathrm{C}$ yr B.P., equivalent to perhaps $\sim 35,000 \mathrm{cal} \mathrm{yr}$ B.P. (Nelson et al., 1979; Madole, 1986). Based on cosmogenic ${ }^{36} \mathrm{Cl}$ and ${ }^{10} \mathrm{Be}$ measurements (corrected for snow shielding) in moraine boulders in the Front Range and Park Range, Pinedale glaciers deposited moraines from $\sim 28,000$ to $\sim 19,000$ cal yr B.P. (Benson et al., 2004). Basal sediments in Front Range cirques suggest that Pinedale glaciers had disappeared by $\sim 14,400-12,200$ cal yr B.P., which are likely minimum ages (see review in Benson et al., 2004). After Pinedale deglaciation, a less extensive glacial advance called the Satanta Peak glaciation occurred in some valleys (Fig. 4) of the Front Range (Benedict, 1973). Geologic mapping indicates that the Satanta Peak advance was perhaps only $\sim 10 \%$ of the Pinedale advance in terms of down-valley extent (Benedict, 1973). Radiocarbon ages also suggest that this ice advance was short-lived, occurring between $\sim 12,000$ and $10,000{ }^{14} \mathrm{C}$ yr B.P. A relatively warm, ice-free, early to mid-Holocene period followed the Satanta Peak glacial advance, and lasted from perhaps around 10,000 to $5,000{ }^{14} \mathrm{C}$ yr B.P. (Benedict, 1973, 1981, 1985). This warm period was followed by "Neoglacial" periods of ice growth (Benedict, 1973, 1981, 1985, 2000) that were limited to advances within the cirques.

Modern climate data for the tundra portions of the Indian Peaks area are sparse, and the closest locality with long-term data is the Niwot Ridge area, $\sim 3 \mathrm{~km}$ to the north. At station D-1, located at an elevation of $3749 \mathrm{~m}$ in the tundra of Niwot Ridge, mean January temperatures for $1950-1980$ are $-13.2^{\circ} \mathrm{C}$ and mean July temperatures are $8.2^{\circ} \mathrm{C}$, with only four months with temperatures above freezing (Greenland, 1989). Mean annual precipitation for this same period is $930 \mathrm{~mm}$, with a maximum in winter and spring. Greenland (1989) points out that the minimum precipitation in this tundra locality occurs during the short growing season.

Degree of winter snow cover is highly variable in the region and is strongly influenced by wind velocity. In areas where strong winds occur, snow cover is patchy during much of the winter, whereas areas protected from strong winds can retain deep snow for long periods. Dust deposition and retention are likely correlated with degree of snow cover because wind velocity exerts a strong control on both. Examination of 1:24,000 aerial photographs taken on 3 March 1994 allowed us to recognize two categories of landscapes in the region, with respect to degree of snow cover: (1) patchy snow (in sheltered depressions and behind rocks or tree islands) with abundant visible bare ground; and (2) continuous snow cover with evidence of wind patterning, such as long, linear drifts in the lee of boulders and tree islands or continuous, unpatterned snow cover.

Vegetation in the Colorado Front Range is strongly conditioned by altitude (Komárková and Webber, 1978). Upper montane forest gives way at higher altitudes $(\sim 2800-2900 \mathrm{~m})$ to subalpine forest dominated by spruce-fir (Picea engelmannii-Abies lasiocarpa) forest (Marr, 1964). Timberline occurs at around 3300-3400 m elevation (Fig. 3), but there is significant variability in timberline elevation as a function of aspect, slope, lithology, and other factors. The foresttundra boundary is not sharp, but is an ecotone, marked by numerous krummholz tree islands (Marr, 1977; Benedict, 1984). Moraines at some localities we studied, such as the Caribou Lake cirque and parts of the Fourth of July Valley, host Picea engelmannii-Abies lasiocarpa krummholz tree islands (Fig. 4). Above timberline, investigators have identified numerous distinct alpine tundra communities, distinguished by moisture conditions, exposure to wind, and amount of snow cover (Komárková and Webber, 1978; Haase, 1987). Well-drained alpine tundra communities host genera such as Kobresia, Artemisia, Carex, Trifolium, Silene, Minuartia, Vaccinium, and Dryas.

Soils in alpine areas of the Colorado Front Range have been studied by many workers, including Burns and Tonkin (1982), Shroba and Birkeland (1983), Birkeland et al. (1987, 2003), and Dixon (1991). Birkeland et al. (2003) provide an excellent overview of the main processes of soil formation as a function of climate and vegetation with increasing elevation from the Colorado Piedmont to the alpine zone in the mountains. With increasing elevation, Mollisols under grassland shift to Alfisols under forest and Inceptisols under tundra.

We sampled soil A horizons on uneroded Satanta Peak moraines or outwash terraces in the Arapaho, Lake Dorothy, Fourth of July (upper and lower), Diamond Lake, Caribou Lake, and Devil's Thumb valleys (Figs. 2-4). The first three of these valleys contain high-altitude cirque moraines with alpine-tundra vegetation and patchy winter snow cover, resulting from exposure to strong winter winds. Moraines on the floors of the Caribou Lake, Fourth of July (lower), Diamond Lake, and Devil's Thumb valleys host tundra, tree islands, or subalpine forest, depending on altitude. Their winter snow cover is continuous, and is unpatterned by wind except in the Caribou Lake valley, where March 1994 aerial photographs show linear snow dunes extending downwind from flagged tree islands. Satanta Peak outwash terraces occur only in 


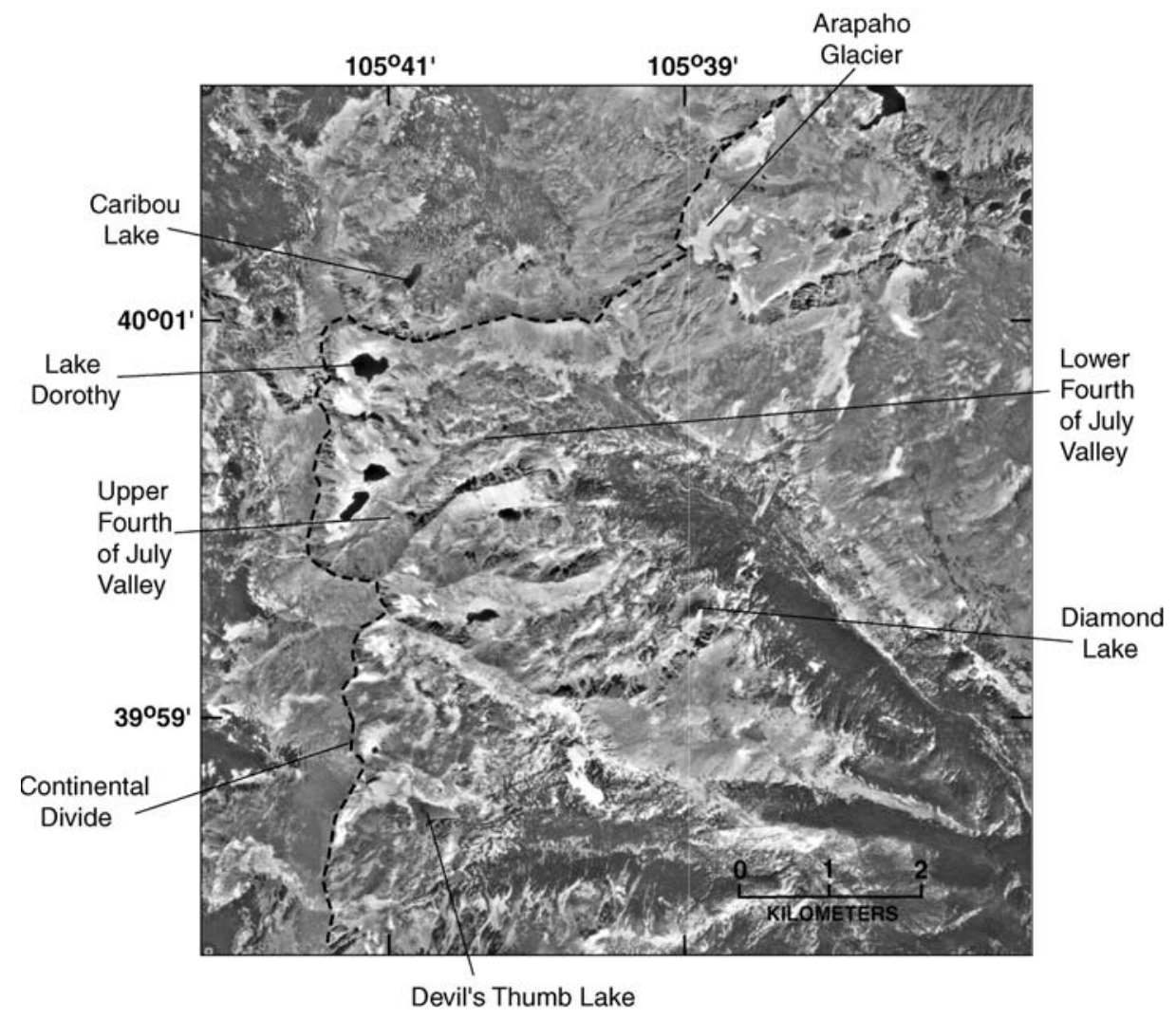

FIGURE 2. Aerial photograph of part of the Indian Peaks region, showing the Continental Divide and cirques where moraines were sampled.

the Fourth of July Valley, where they are covered in winter by deep, unpatterned snow.

\section{Methods}

At most localities, soils were sampled at $0-10$ or $0-20 \mathrm{~cm}$ depths, depending on the thickness of the A horizon. We also collected representative bedrock clasts found in the till of each moraine or outwash deposit. Finally, we collected samples of modern alluvium from streams that integrate sediments from various rock types in Middle Park and North Park (Fig. 1), two semiarid basins that are the closest potential upwind sources of eolian particles. In North Park, we collected modern alluvium from the North Platte River, Grizzly Creek, Illinois River, and Michigan River. In Middle Park, we collected alluvium from the Colorado River, Muddy Creek, and Troublesome Creek.

Soils were analyzed for particle size distribution, mineralogy, and geochemistry. Particle size distributions were determined for the entire "fine earth" fraction of soil A horizons (all particles less than $2 \mathrm{~mm}$ diameter). Thus, our particle size analyses measure the amounts of all particles smaller than gravel. We used a Malvern model MSSL shortbed laser particle size analyzer (use of trade names is for descriptive purposes only and does not imply endorsement by the U.S. Geological Survey [USGS]), after destruction of organic matter with hydrogen peroxide and dispersion with Na-hexametaphosphate. It is important to note that particle size distributions using laser granulometry do not always agree with particle size distributions determined by other methods (Konert and Vandenberghe, 1997; Buurman et al., 2001; Mason et al., 2003). Because of these methodological problems, we also present new, laser-granulometric analyses of known loess deposits from eastern Colorado and dust-trap samples from the Mojave Desert of Nevada and California. For geochemical analyses, rocks were analyzed as bulk samples after pulverization. For soil A horizons, the sands (2000-53 $\mu \mathrm{m}$ fraction) and silts (53-2 $\mu \mathrm{m}$ fraction) were analyzed separately. All Middle Park and North Park alluvial sediments were analyzed for the silt fractions $(53-2 \mu \mathrm{m})$ only. Sands and silts were separated by wet-sieving after destruction of organic matter with hydrogen peroxide and dispersion with Na-pyrophosphate. Silts were isolated from clays by repeated settling and decantation. Sand and silt separates and bulk rocks were pulverized and analyzed for trace element concentrations using energy-dispersive X-ray fluorescence (XRF). Each run included USGS rock standard GSP-1 (Silver Plume Granite).

\section{Hypotheses}

Our goal in this study was to test two alternative hypotheses about the origin of silt-rich soil A horizons in the alpine tundra zone of the Colorado Front Range. One hypothesis is that the silts are locally derived and the other is that they have an eolian origin from a distant source or sources. Local derivation could be from one or more of the following processes: (1) inheritance of silt-sized particles, produced by glacial grinding, as a component of the till in which the soil formed; (2) in situ production of silt-sized particles by frost shattering, subsequent to till deposition; and (3) short-distance eolian transport to the moraines from nearby valleys, during or after till deposition. If the silts are locally derived, their composition should be similar to the sands, and both silts and sands should be similar in composition to the local bedrock. Furthermore, particle size distributions of bulk soil A horizons will not likely resemble those of loess deposits, even if there is a local eolian component. If the silts have a distant eolian source, particle size distributions should be similar to loess deposits, but silts will likely have a composition that differs from the sand fraction and local bedrock. 

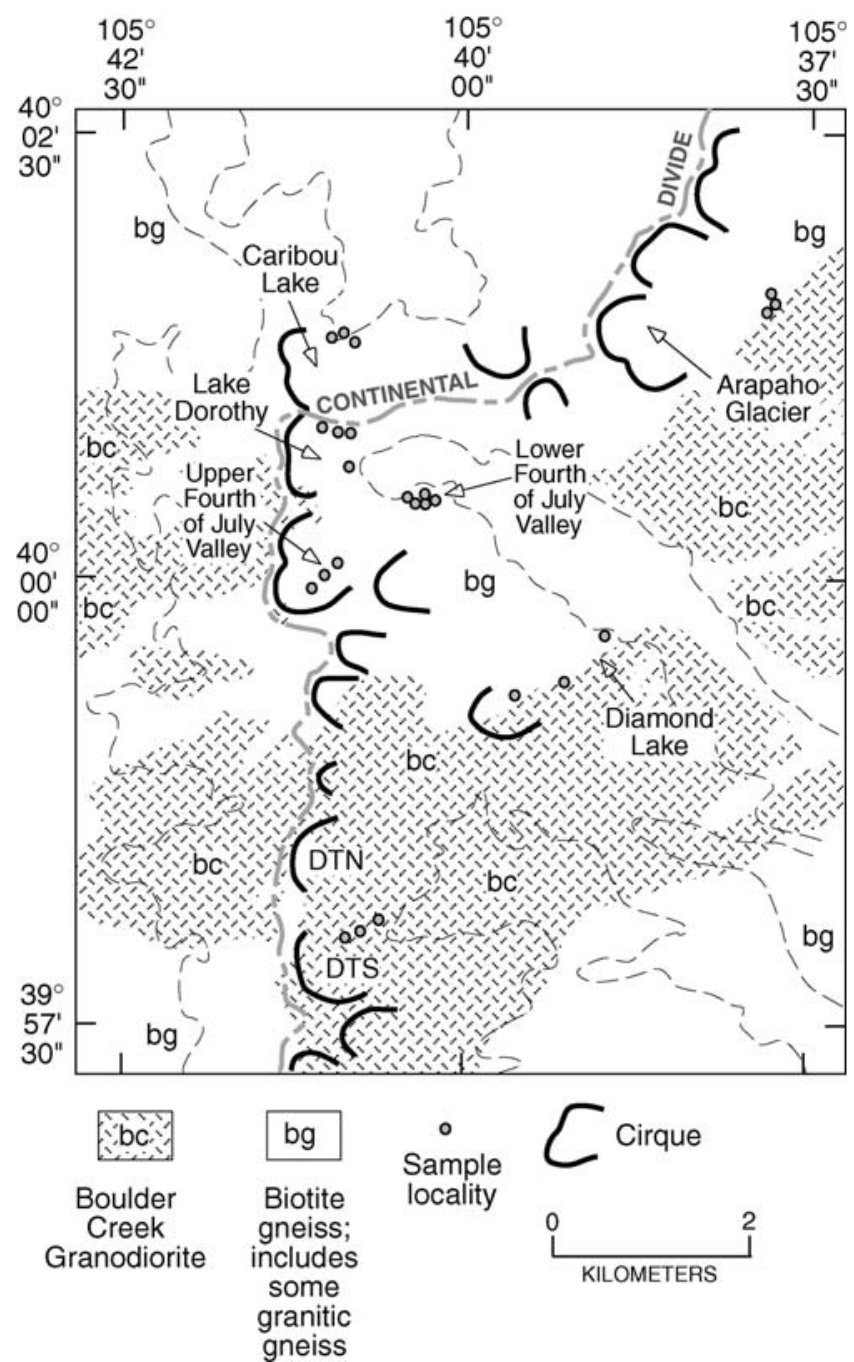

FIGURE 3. Map of the study area, showing major bedrock types (simplified from Pearson, 1980), cirques, sample localities, and approximate timberline (thin dashed line). DTN-Devil's Thumb north cirque; DTS-Devil's Thumb south cirque.

\section{Results and Discussion}

\section{PARTICLE SIZE DISTRIBUTION OF ALPINE SOILS IN THE COLORADO FRONT RANGE}

Colorado Front Range surface soils are finer textured and less well sorted than dune sands, but their mean particle sizes and sorting are similar to those of loess and dust deposits (Fig. 5). Particle-size distributions vary from cirque to cirque and, with one exception, correlate closely with degree of snow cover. At localities characterized by patchy snow cover, such as the Lake Dorothy, Arapaho, and upper Fourth of July Valley cirques, mean particle size is relatively coarse (very fine sand and coarse silt). In contrast, the other localities, all characterized by continuous snow cover, have finer mean particle sizes (coarse silt, medium silt, or fine silt).

Histograms (Fig. 6) show the relative abundance of each particle size class in Front Range soils and facilitate comparison with other sediments. In all Front Range soils, the modal particle size is in the sand $(2000-53 \mu \mathrm{m})$ fraction, but there is a fairly even distribution of the various silt particle-size classes and clay $(<2 \mu \mathrm{m})$ fraction. Secondary modes are present in the coarse silt $(53-22 \mu \mathrm{m})$ and clay fractions. Mean particle sizes of Front Range soils span a generally coarser range than Mojave Desert dusts, due largely to their higher sand content (Fig. 5). Nevertheless, Front Range soils have similar abundances of silt-sized particles and generally have higher clay contents than Mojave Desert dust samples (Figs. 6, 7). In addition, Front Range soils show similarities to the particle size spectra shown in the histograms for eastern Colorado loess (Fig. 7). In fact, some of the finer-silt classes show greater abundances in Front Range soils than they do in eastern Colorado loesses.

\section{USE OF TRACE ELEMENT GEOCHEMISTRY AND DIFFERENTIATION OF ROCK TYPES}

Geochemistry of rocks, sediments, and soils reflects their mineralogy. In the Indian Peaks study area, biotite gneiss contains biotite, quartz, and plagioclase, with lesser amounts of sillimanite, Kfeldspar, garnet, and cordierite (Pearson, 1980). Boulder Creek Granodiorite contains plagioclase, quartz, K-feldspar, and biotite, with smaller amounts of hornblende, muscovite, sphene, zircon, and apatite (Gable, 1980). Based on X-ray diffraction analysis and microscopic

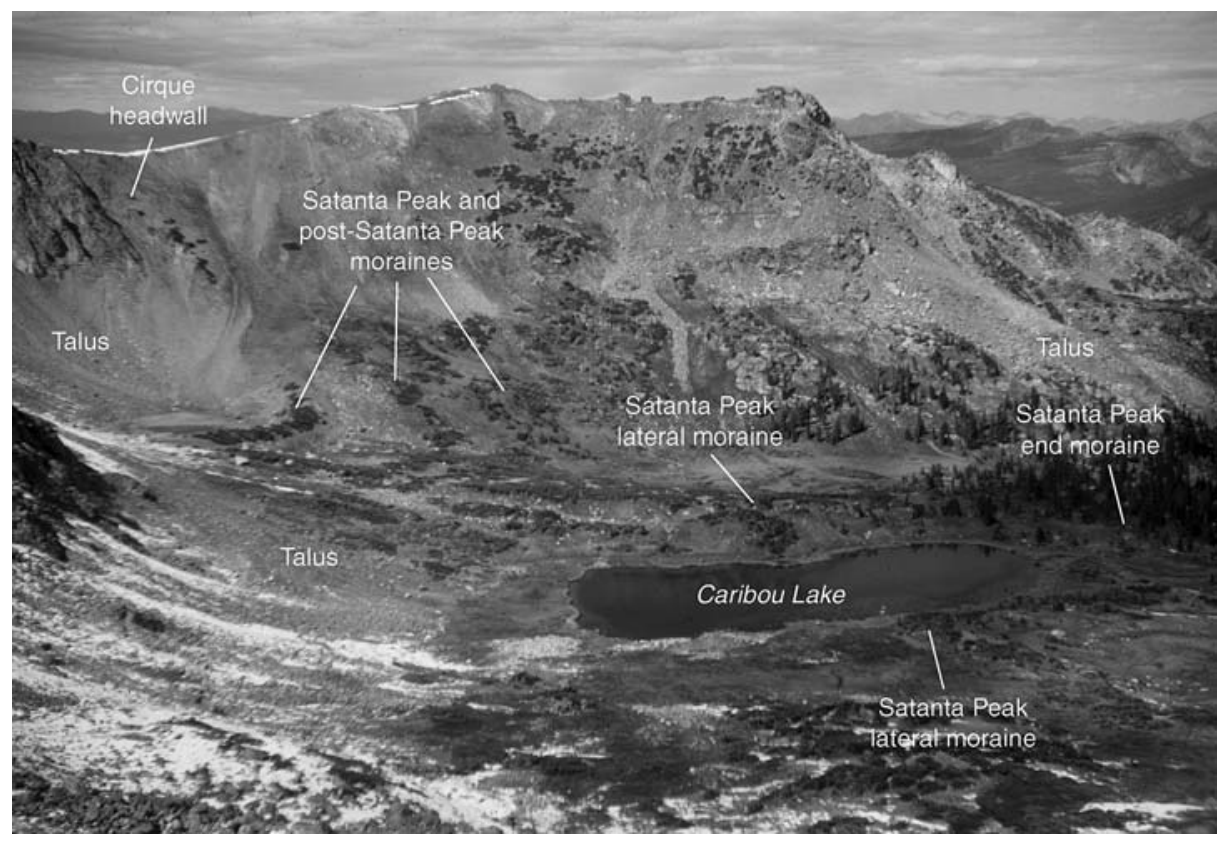

FIGURE 4. View of Caribou Lake cirque from near Arapaho Pass, showing Satanta Peak and younger moraines, some with tree islands. Photograph by $D$. R. Muhs.

D. R. Muhs And J. B. Benedict / 123 


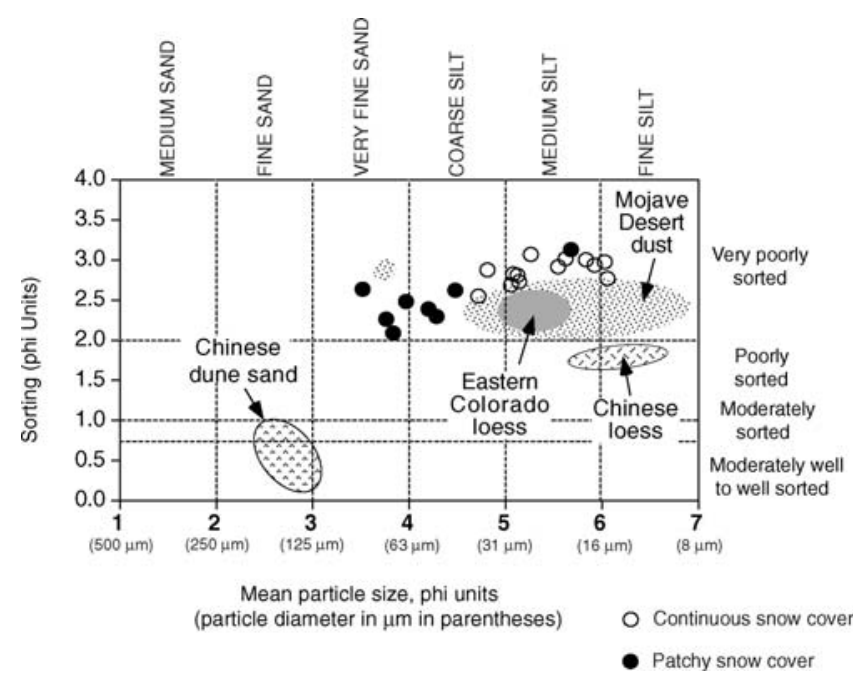

FIGURE 5. Plot of mean particle size and degree of sorting (standard deviation of the mean particle size) of silt-enriched mantles from Front Range moraines and outwash terraces and polygons showing the ranges of these values for various other eolian sediments. Open circles are Front Range localities with continuous snow cover; filled circles are localities with patchy snow cover, as seen on aerial photographs taken on 3 March 1994. Eastern Colorado loess data are from localities also shown in Figure 7 and described in Muhs et al. (1999). Mojave Desert data are from Reheis (2003). Chinese dune sand data are from the Taklimakan Desert and are from Wang et al. (2002); Chinese loess data are from the Luochuon and Xifeng sections and are from Lu et al. (2001). All analyses done by laser particle size methods.
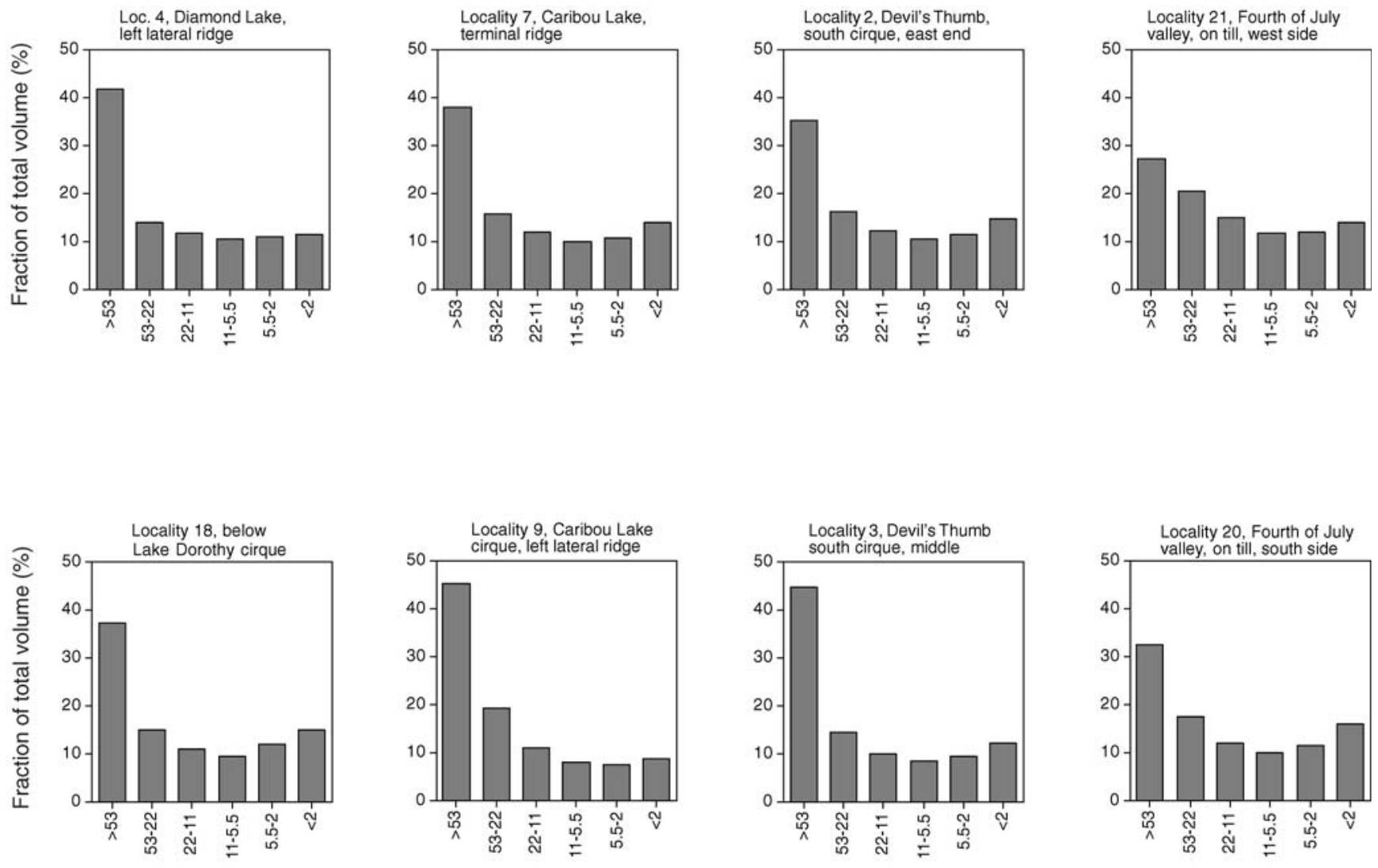

Particle size class $(\mu \mathrm{m})$ examination, the sand fractions of the alpine soils we studied consist of quartz, K-feldspar, plagioclase, biotite, amphibole (probably hornblende), and sillimanite. Silt-sized particles cannot be identified microscopically, but X-ray diffraction analysis shows that quartz, $\mathrm{K}$-feldspar, plagioclase, and mica (which could be either biotite or muscovite) are all present.

In studying possible eolian additions to soils, it is essential to use only chemically immobile elements. We chose the elements $\mathrm{Ti}, \mathrm{Zr}, \mathrm{Nb}$, $\mathrm{Ce}$, and $\mathrm{Y}$, all of which have a relatively high ionic potential and are considered to be chemically immobile under most near-surface environments (Hutton, 1977; Taylor and McLennan, 1985; McLennan, 1989). $\mathrm{Ti}$ and $\mathrm{Nb}$ are found in ilmenite, rutile, anatase, titanomagnetite, and sphene. These two elements can also be present in biotite. In most rocks, sediments, and soils, zircon is the exclusive host of Zr. Both Ce (a light rare earth element) and Y (an element that has chemical properties similar to middle rare earth elements) are found in trace amounts in a wide variety of minerals. Rare earth elements and $\mathrm{Y}$ can be found in micas, chlorite, clay minerals, sphene, and amphiboles, and they are concentrated in monazite and apatite. Pearson (1980, p. 46) thought that monazite was the main source of rare earth elements and $\mathrm{Y}$ in rocks of the Indian Peaks area. Petrologists have previously used Ti, Zr, Nb, Ce, and $\mathrm{Y}$ in studying the origins of igneous and metamorphic rocks (Pearce and Cann, 1973; Meschede, 1986), and soil scientists have used Ti and $\mathrm{Zr}$ as indicators of multiple parent materials (Hutton, 1977).

One concern we had was the potential for geochemical bias by size fractionation of minerals. If such a bias occurred, the result could be that sands and silts could have compositional differences even if derived from the same rock. DiLabio (1989) showed that in tills of

FIGURE 6. Histograms showing relative proportions of various particle size classes in Front Range silt-enriched mantles. All analyses done using a laser particle size analyzer at the U.S. Geological Survey. Note that the examples given here are the samples with the finest grain size; samples from Arapaho cirque and Lake Dorothy cirque have higher sand and lower silt contents (see text for discussion). 

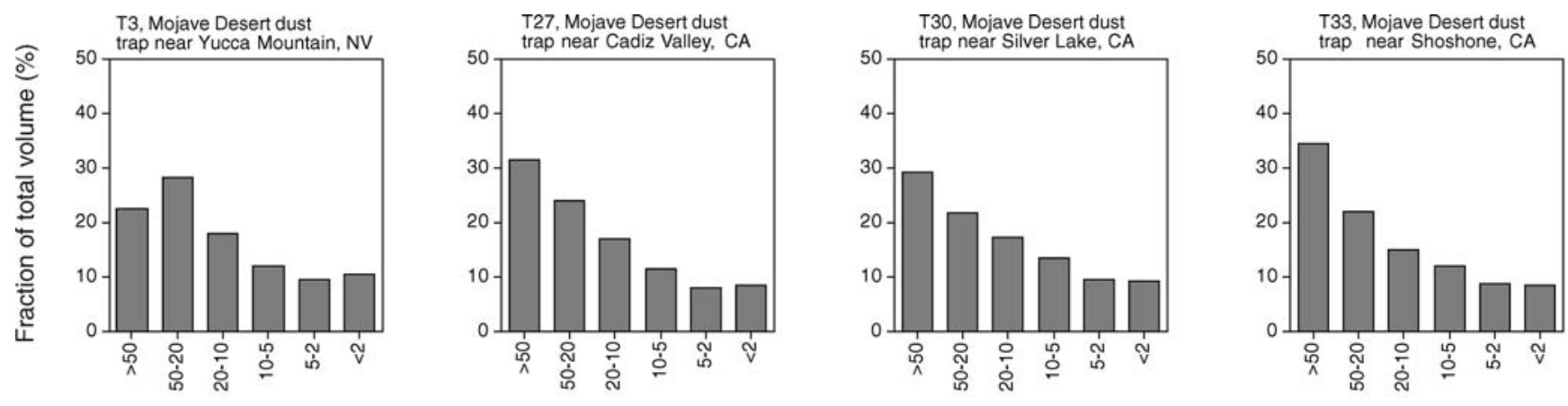

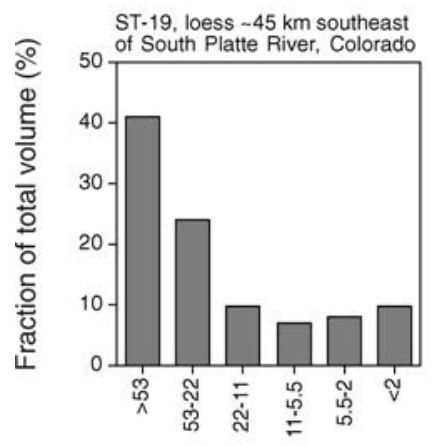

Particle size class $(\mu \mathrm{m})$

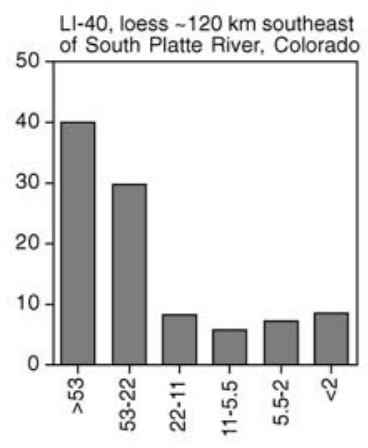

Particle size class $(\mu \mathrm{m})$

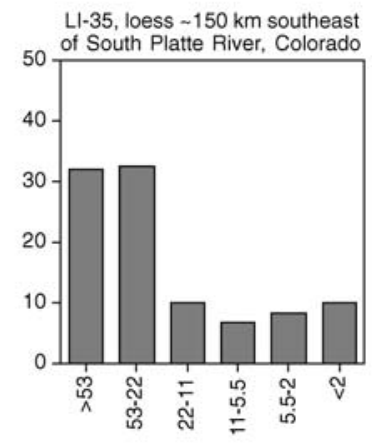

Particle size class $(\mu \mathrm{m})$

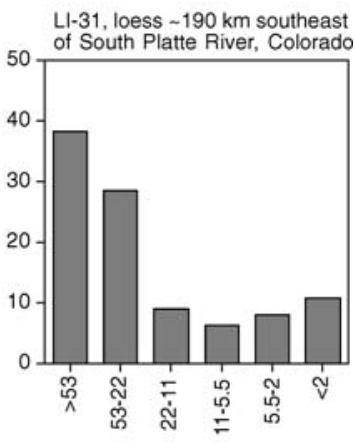

Particle size class $(\mu \mathrm{m})$

FIGURE 7. Histograms showing relative proportions of various particle size classes in Mojave Desert dust, collected in traps in the spring of 2002 (see Reheis, 2003, and Reheis et al., 2002, for localities and other data) and loess from eastern Colorado (see Muhs et al., 1999, for localities). All analyses done using a laser particle size analyzer at the U.S. Geological Survey. Note that particle size classes for Mojave Desert dust differ slightly from Colorado loess and samples in Figure 6.

Quebec and Newfoundland, $\mathrm{Zr}, \mathrm{Nb}$, and $\mathrm{Y}$ have their highest concentrations in the silt and clay $(<0.063 \mathrm{~mm})$ and coarse sand $(2.0-0.5 \mathrm{~mm})$ fractions and lowest concentrations in the mediumto-fine $(0.5-0.125 \mathrm{~mm})$ sand fractions. We plotted concentrations of $\mathrm{Zr}, \mathrm{Nb}, \mathrm{Y}$, and $\mathrm{Ti}$ in the sand fractions of our soils as a function of the amount of medium and fine $(0.5-0.125 \mathrm{~mm})$ sand (expressed as a percentage of the total, $2.0-0.053 \mathrm{~mm}$, sand fraction). If there were a particle size bias, we would have expected strong, negative linear correlations of element concentrations as a function of the amount of medium and fine sand. None of the four elements shows a systematic relation with amount of medium and fine sand, and coefficients of determination $\left(r^{2}\right)$ for linear regression equations range from 0.13 to 0.001 . We conclude that there is no significant bias by particle size within the sand fraction.

In order to ascertain whether the element suite chosen can be useful in identifying eolian additions to alpine soils, we conducted two experiments. The first experiment was to analyze loess deposits from different regions to determine if element ratios could discriminate eolian silts that are known, a priori, to have different source sediments. For this we analyzed late Pleistocene and/or Holocene loess from four sections in central Alaska, near Fairbanks (Muhs et al., 2003), Holocene loess from three sections in the Matanuska Valley of southern Alaska (Muhs et al., 2004), late Pleistocene (Peoria) loess from a number of localities in Nebraska (Muhs et al., 1999) and late Pleistocene (Peoria) loess from a thick section near Morrison, Illinois, just east of the Mississippi River (Muhs et al., 2001; Bettis et al., 2003). $\mathrm{Ti} / \mathrm{Zr}$ vs. $\mathrm{Ti} / \mathrm{Nb}$ show that loesses from these widely separated regions define distinct compositional fields, with minimal overlap (Fig. 8). Ti/Zr values easily distinguish both Alaskan loesses from both midcontinent loesses, and $\mathrm{Ti} / \mathrm{Nb}$ values distinguish the two Alaskan loesses and the two midcontinent loesses from each other. $\mathrm{Ce} / \mathrm{Y}$ values are a measure of the abundances of the light rare earth elements to the middle rare earth elements, which can vary from sediment and rock type (Taylor and McLennan, 1985; McLennan, 1989). For the loess sediments examined here, $\mathrm{Ce} / \mathrm{Y}$ appears to be a less useful provenance indicator than either $\mathrm{Ti} / \mathrm{Zr}$ or $\mathrm{Ti} / \mathrm{Nb}$.

The second experiment was to examine the whole-rock chemistry of the two major rock types in the study area, biotite gneiss and granodiorite (and other granitic rocks). With the exception of the Devil's Thumb south cirque (dominantly in Boulder Creek Granodiorite) and Upper Diamond Lake (in both biotite gneiss and Boulder Creek Granodiorite), our study cirques are cut in biotite gneiss. Nevertheless, as pointed out by Birkeland et al. (1987), there are lenses of granodiorite within the biotite gneiss bedrock of Arapaho cirque. We found granodiorite and granite clasts in the moraines of all cirques we studied. $\mathrm{Ti} / \mathrm{Zr}$ and $\mathrm{Ti} / \mathrm{Nb}$ values show a wide range of variability for biotite gneiss (Fig. 8). This finding is consistent with that of Young (1991), who showed that biotite gneiss in the study area has a composition that ranges from ultramafic to granitic. In contrast, Ti/ $\mathrm{Zr}$ and $\mathrm{Ti} / \mathrm{Nb}$ show only a modest range of variability for granitic rocks. Values for $\mathrm{Ce} / \mathrm{Y}$, however, show about the same range of variability for both rock types. For the purpose of provenance studies, however, the most important finding is that $\mathrm{Ti} / \mathrm{Zr}$ and $\mathrm{Ti} / \mathrm{Nb}$ for the two rock types show little or no overlap. 

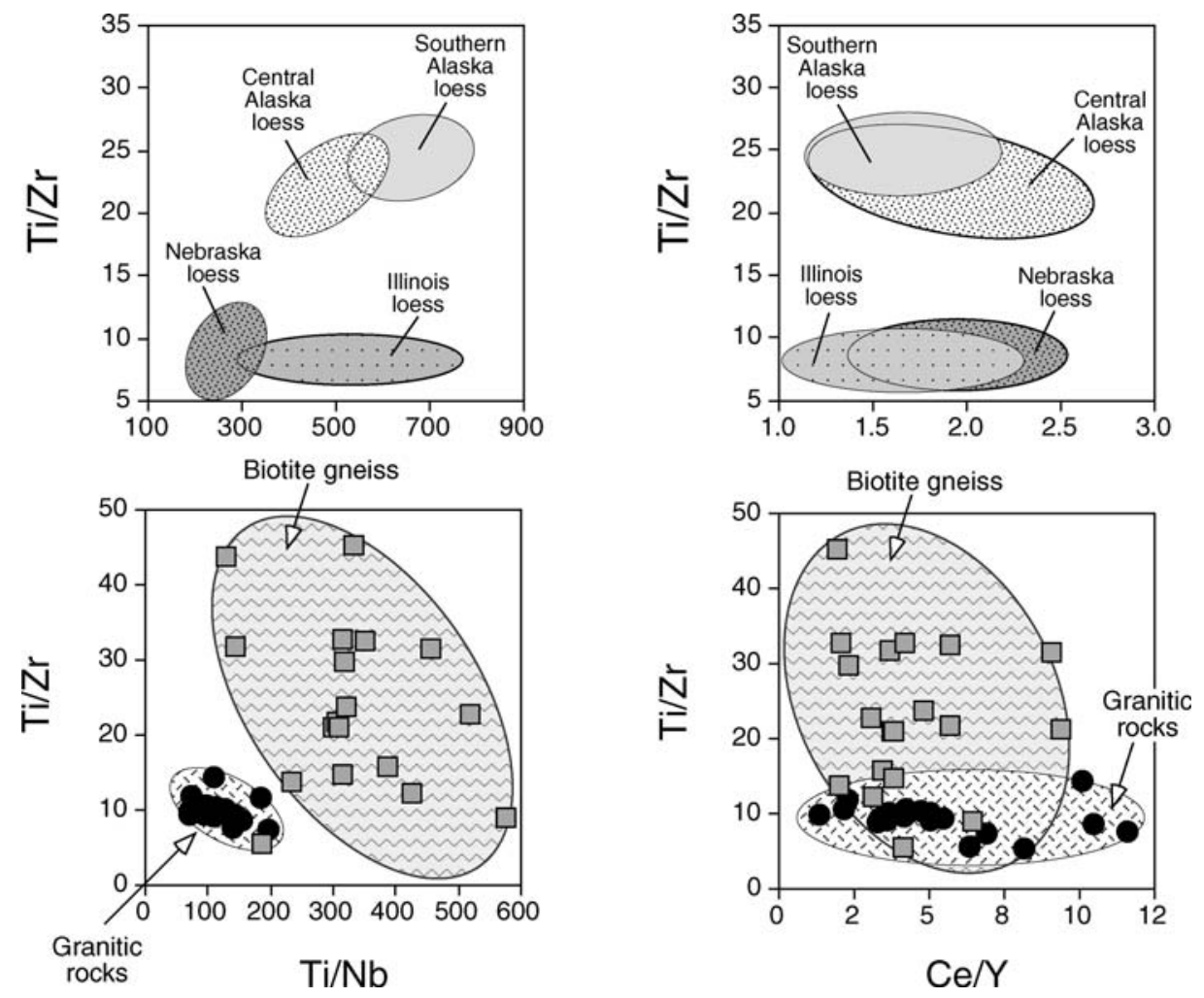

FIGURE 8. (Upper) Comparison of $\mathrm{Ti} / \mathrm{Zr}$, $\mathrm{Ti} / \mathrm{Nb}$, and $\mathrm{Ce} / \mathrm{Y}$ for bulk loesses from various localities elsewhere in North America. See text for description and references on the various loess localities. (Lower) Comparison of $\mathrm{Ti} / \mathrm{Zr}$, $\mathrm{Ti} / \mathrm{Nb}$, and $\mathrm{Ce} / \mathrm{Y}$ for biotite gneisses and granitic rocks of the Indian Peaks Wilderness area. All rocks collected from Satanta Peak moraines in the cirques shown in Figures 2 and 3.

\section{TRACE ELEMENT GEOCHEMISTRY OF SOIL A HORIZONS}

The trace element geochemistry of the sand $(2000-53 \mu \mathrm{m})$ fractions of soil A horizons shows a composition that is very similar to that of biotite gneiss (Fig. 9). This result is not surprising, because biotite gneiss is the major rock type in the area (Pearson, 1980), even though granitic lenses are common in the gneiss. It is also possible that glacial grinding of rocks to sand-sized particles is more effective on biotite gneiss than it is on granodiorite.

The compositions of the silt $(53-2 \mu \mathrm{m})$ fractions of the soils are significantly different from the sand fractions (Fig. 9). Ti/Zr, Ti/Nb,

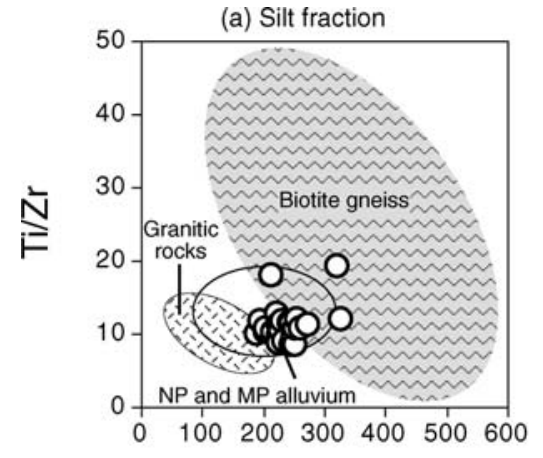

$\mathrm{Ti} / \mathrm{Nb}$

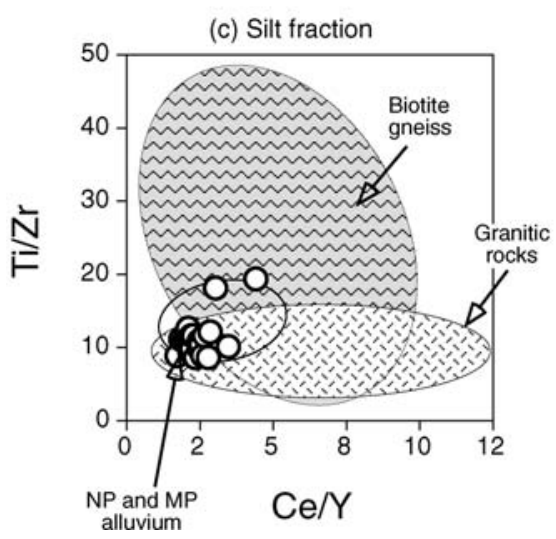

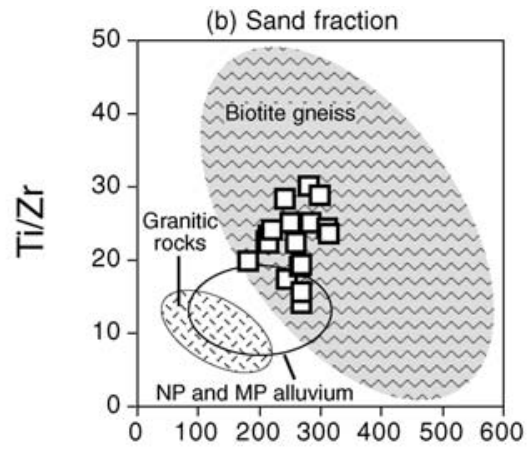

$\mathrm{Ti} / \mathrm{Nb}$

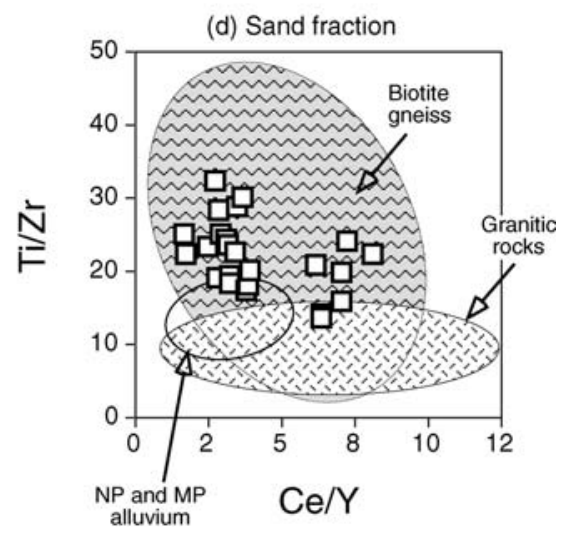

FIGURE 9. Comparison of Ti/ $\mathrm{Zr}, \mathrm{Ti} / \mathrm{Nb}$, and $\mathrm{Ce} / \mathrm{Y}$ for sand and silt fractions from soils in the study area. Shaded polygons show the range of these values for biotite gneisses and granitic rocks (Fig. 8), and open polygons show the range of values for North Park (NP) and Middle Park (MP) alluvial silts. 


\section{COLORADO}

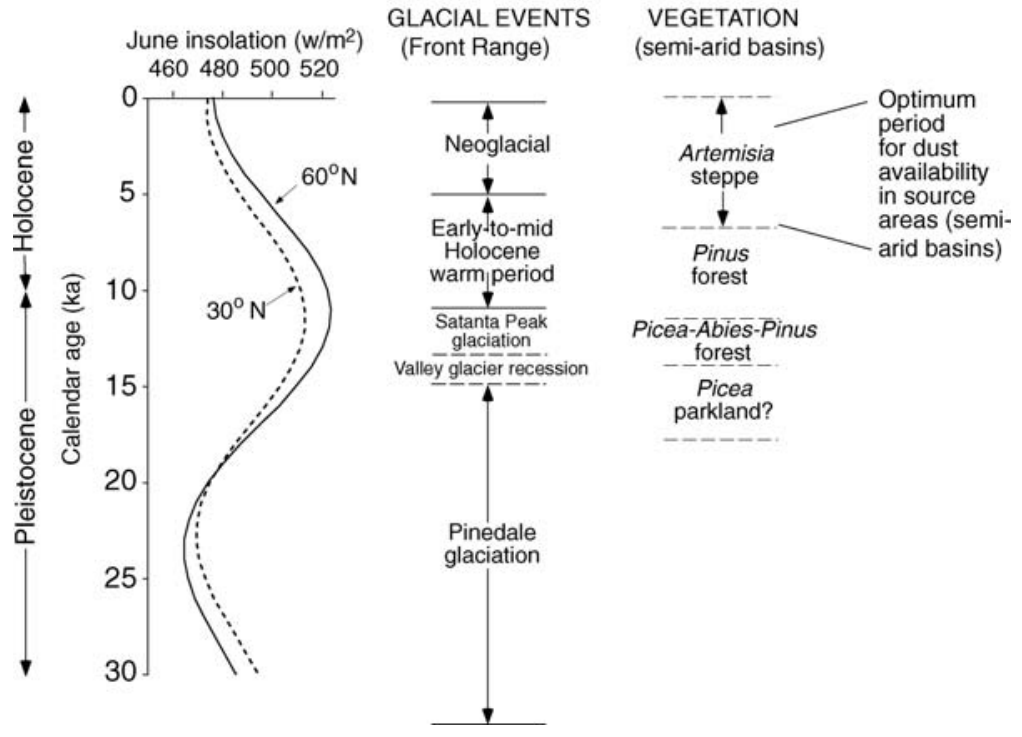

FIGURE 10. Comparison of June insolation at the top of the atmosphere in the Northern Hemisphere at two latitudes (data from Berger and Loutre, 1991), glacial events in the Colorado Front Range (Benedict, 1973, 1981), and pollen records for semiarid basins of Colorado (Fall, 1997) for the last glacialinterglacial cycle. Also shown is the period in the mid-Holocene when dust source flux from semiarid source basins was enhanced.

and even $\mathrm{Ce} / \mathrm{Y}$ values for the silt fractions show much more restricted ranges than do the sand fractions or whole-rock samples of biotite gneiss. We expected that if the silt-sized particles in these soils were derived from the local bedrock, produced either by glacial grinding or frost shattering, they would have a composition that is similar to the sand fraction and the local biotite gneiss. Based on the intermediate composition of the silts compared to the biotite gneiss and granitic rocks (Fig. 9), it could be argued that the silts are derived from some combination of the two bedrock types. If the local granitic rocks produced silt-sized particles, we would have expected that they also would have produced sand-sized particles. $\mathrm{Ti} / \mathrm{Zr}$ and $\mathrm{Ti} / \mathrm{Nb}$ values suggest, however, that granitic rocks contribute little to the sand fraction (Fig. 9). Furthermore, if both rock types contributed to the generation of the silt fraction, it is difficult to understand how this would result in a smaller range of compositional variability than what is found in the sand fraction or in either rock type. We conclude, therefore, that the sands are derived dominantly, if not wholly, from the local biotite gneiss bedrock, and the silts are not derived primarily from either bedrock type. Thus, the trace element chemistry of the silt fraction eliminates the hypothesis that the silts are locally derived, from glacial grinding, frost shattering, or local eolian transport.

\section{TRACE ELEMENT GEOCHEMISTRY OF SOIL A HORIZONS COMPARED TO DISTANT SOURCES}

The composition and particle size distribution of the alpine soil A horizons suggest a non-local eolian origin for the silt-sized particles. The two closest potential sources of distant eolian silts to the study area are North Park and Middle Park, which are structural and topographic basins situated to the west of the Front Range (Fig. 1). Both basins are semiarid, with a relatively sparse sagebrush and grass vegetation cover. Part of the sediment in these basins is derived from the same Front Range rocks that crop out in the cirques. In addition, however, there are compositionally distinct bedrock types in the basins, such as the Tertiary Troublesome Formation, a volcaniclastic siltstone, and the Cretaceous Pierre Shale, a dark-gray marine shale. Fine-grained residuum from these rocks is widely distributed (Madole, 1991a, 1991b), easily eroded, and likely to contribute sediment to drainages within these semiarid basins. Alluvium collected from a variety of rivers and streams in North Park and Middle Park was fractionated to obtain silt-sized $(53-2 \mu \mathrm{m})$ particles, which were analyzed for the same elements as the other sediments and rocks. Silts in North Park and Middle Park have $\mathrm{Ti} / \mathrm{Zr}$ and $\mathrm{Ti} / \mathrm{Nb}$ values that are intermediate between the fields occupied by Front Range granitic rocks and biotite gneiss (Fig. 9). The alluvial silts also have $\mathrm{Ce} / \mathrm{Y}$ values that are relatively restricted compared to both Front Range rock types. Overall, the geochemical match between North Park and Middle Park basin silts and alpine-soil silts is excellent. These observations suggest that the source of eolian silt in the Front Range is either or both of these two semiarid basins. If so, this would require eolian transport distances of $\sim 60 \mathrm{~km}$ (distance from Middle Park east to the Indian Peaks area) to $\sim 100 \mathrm{~km}$ (distance from North Park east to the Indian Peaks area). The particle size histograms for most alpine soils in the Indian Peaks region show percentages of fine silts as high or higher as those for last-glacial loess at localities in eastern Colorado (Figs. 6, 7). Loess at these localities is derived from sediments of the South Platte River and the White River Group (Aleinikoff et al., 1999), exposed $\sim 45$ to $\sim 190 \mathrm{~km}$ northwest of the loess localities. Compared to eastern Colorado loesses, the relatively fine texture of the Indian Peaks soils suggests that particle transport from sources at least as far away as $60-100 \mathrm{~km}$ is feasible.

\section{TIMING OF EOLIAN SILT ADDITIONS TO FRONT RANGE ALPINE SOILS}

In the period between the last (Pinedale) glaciation and the present, the shift from a glacial to an interglacial climate was likely caused, or certainly enhanced, by an increase in incoming solar radiation during summer over mid- to high latitudes of the Northern Hemisphere (Fig. 10). Over this time period, there were significant changes in vegetation in Colorado. Pollen studies show that timberline apparently rose in the high mountains of Colorado, with a Picea-Abies forest at higher elevations than during the last glacial period (Fall, 1997). During the same time period, in semiarid basins of mountainous Colorado, vegetation shifted from a Picea-Abies-Pinus cover during the late glacial period to a less dense Pinus forest and then Artemisia steppe during the early and mid-Holocene (Fall, 1997). Thus, during the mid-Holocene, semiarid basins such as Middle Park and North Park may have had a relatively sparse vegetation cover, at least compared to the last glacial period. If this scenario is correct, then sediment availability for eolian transport from semiarid basins may have been at a maximum during the mid-Holocene (Fig. 10). 
Another Colorado study suggests that much of the eolian silt accumulation in Front Range soils may have occurred during the midHolocene. Andrews et al. (1985) studied sediments in Blue Lake, also situated within the Indian Peaks Wilderness Area, $\sim 7 \mathrm{~km}$ north of Arapaho cirque. This study shows that silt, which Andrews et al. (1985) interpret to be eolian, is the dominant particle size in the lake sediments throughout their cores. Nevertheless, silt accumulation rates have a maximum during the mid-Holocene, between $\sim 7880$ and $\sim 5500{ }^{14} \mathrm{C}$ yr B.P. An increase in sediment availability for eolian transport in semiarid basins such as North Park and Middle Park would explain why hypothesized eolian sediment accumulation in Blue Lake reached its maximum rate in the mid-Holocene.

\section{Conclusions}

In numerous cirques of the Indian Peaks Wilderness Area of the Colorado Front Range, soils on moraines of late-glacial age have A horizons that are enriched in silt. Detailed analyses show that these soils have particle size distributions very similar to other fine-grained eolian sediments, such as Chinese loess, eastern Colorado loess, and modern dust in the Mojave Desert.

Studies of loesses from widely separated regions of North America (Illinois, Nebraska, and Alaska) show that certain immobile trace element ratios, particularly $\mathrm{Ti} / \mathrm{Zr}$ and $\mathrm{Ti} / \mathrm{Nb}$, can be useful provenance indicators. Both major bedrock types in the Indian Peaks region (biotite gneiss and granodiorite) have different ratios for these elements, as do the sand and silt fractions of soils on Satanta Peak moraines. Sands have compositions that are not significantly different from biotite gneiss, the main bedrock type in this part of the Front Range. However, silts do not appear to be derived from the local bedrock, which eliminates their origin as inheritance from glacial grinding, in situ frost shattering, or local eolian accumulation.

The combination of a distinct geochemistry and a particle size distribution similar to known loess deposits suggests that silts in Front Range alpine soils are eolian, derived from distant sources. Geochemical data and considerations of particle size indicate that Middle Park and North Park—semiarid basins upwind of the Front Range—are candidates as source regions for eolian silt.

Pollen and lacustrine studies elsewhere in Colorado indicate that the main period of eolian silt deposition in the Colorado Front Range may have been during a warmer mid-Holocene period. During this interval, it is likely that source basins to the west, such as Middle Park and North Park, were less well vegetated, and sediment availability for eolian transport was greater.

Addition of eolian silt to alpine soils likely increases their fertility in a nutrient-limited ecosystem. Fine-grained sediments (eolian silts and possibly clays) increase nutrient $(\mathrm{Ca}, \mathrm{Mg}, \mathrm{K}, \mathrm{N})$ content and nutrient-holding capacity, as well as moisture-holding capacity. Eolian additions may also have increased the fertility of soils in the subalpine forest, which is also a nutrient-limited ecosystem (Arii and Turkington, 2002). Future studies should be conducted on the possibility of eolian additions to subalpine and montane forest ecosystems.

\section{Acknowledgments}

This study was supported by the Earth Surface Dynamics Program of the USGS and is a contribution to the "Eolian History of North America" project. The U.S. Forest Service allowed us to sample the soils studied here. Art Bettis kindly allowed us use of loess samples from Morrison, Illinois, that he helped obtain. We thank Jossh Beann, Brian Marshall, Shannon Mahan, Gary Skipp, and Eric Fisher for assistance with the laboratory analyses. Marith Reheis kindly provided unpublished particle size data from her Mojave Desert dust traps. We appreciate helpful discussions with Ralph Shroba. Suzanne Anderson, Paul Carrara, Walt Dean, Gabriel Filippelli, and an anonymous reviewer read an earlier version of the manuscript and made many helpful suggestions for its improvement.

\section{References Cited}

Aleinikoff, J. N., Muhs, D. R., Sauer, R., and Fanning, C. M., 1999: Late Quaternary loess in northeastern Colorado, Part II- $\mathrm{Pb}$ isotopic evidence for the variability of loess sources. Geological Society of America Bulletin, 111: 1876-1883.

Andrews, J. T., Birkeland, P. W., Harbor, J., Dellamonte, N., Litaor, M., and Kihl, R., 1985: Holocene sediment record, Blue Lake, Colorado Front Range. Zeitschrift für Gletscherkunde und Glazialgeologie, 21: 25-34.

Arii, K., and Turkington, R., 2002: Do nutrient availability and competition limit plant growth of herbaceous species in the boreal forest understory? Arctic, Antarctic, and Alpine Research, 34: 251-261.

Bäumler, R., 2001: Pedogenic studies in aeolian deposits in the high mountain area of eastern Nepal. Quaternary International, 76/77: 93-102.

Benedict, J. B., 1973: Chronology of cirque glaciation, Colorado Front Range. Quaternary Research, 3: 584-599.

Benedict, J. B., 1981: The Fourth of July Valley. Glacial geology and archeology of the timberline ecotone. Ward, Colorado: Center for Mountain Archeology, Research Report, 2: 1-139.

Benedict, J. B., 1984: Rates of tree-island migration, Colorado Rocky Mountains, USA. Ecology, 65: 820-823.

Benedict, J. B., 1985: Arapaho Pass. Glacial geology and archeology at the crest of the Colorado Front Range. Ward, Colorado: Center for Mountain Archeology, Research Report, 3: 1-197.

Benedict, J. B., 2000: Game drives of the Devil's Thumb Pass area. In Cassells, E. S. (ed.), This Land of Shining Mountains: Archeological Studies in Colorado's Indian Peaks Wilderness Area. Ward, Colorado: Center for Mountain Archeology, Research Report, 8: 18-94.

Benson, L., Madole, R., Phillips, W., Landis, G., Thomas, T., and Kubik, P., 2004: The probable importance of snow and sediment shielding on cosmogenic ages of north-central Colorado Pinedale and pre-Pinedale moraines. Quaternary Science Reviews, 23: 193-206.

Berger, A., and Loutre, M. F., 1991: Insolation values for the climate of the last 10 million years. Quaternary Science Reviews, 10: 297-317.

Bettis, E. A., III, Muhs, D. R., Roberts, H. M., and Wintle, A. G., 2003: Last glacial loess in the conterminous U.S.A. Quaternary Science Reviews, 22: 1907-1946.

Birkeland, P. W., Burke, R. M., and Shroba, R. R., 1987: Holocene alpine soils in gneissic cirque deposits, Colorado Front Range. U.S. Geological Survey, Bulletin, 1590: $21 \mathrm{pp}$.

Birkeland, P. W., Shroba, R. R., Burns, S. F., Price, A. B., and Tonkin, P. J., 2003: Integrating soils and geomorphology in mountains-an example from the Front Range of Colorado. Geomorphology, 55: 329-344.

Bockheim, J. G., and Koerner, D., 1997: Pedogenesis in alpine ecosystems of the eastern Uinta Mountains, Utah, U.S.A. Arctic and Alpine Research, 29: 164-172.

Bowman, W. D., Theodose, T. A., Schardt, J. C., and Conant, R. T., 1993: Constraints of nutrient availability on primary production in two alpine tundra communities. Ecology, 74: 2085-2097.

Burns, S. F., and Tonkin, P. J., 1982: Soil geomorphic models and spatial distribution and development of alpine soils. In Thorn, C. E. (ed.), Space and Time in Geomorphology. London: Allen and Unwin, 25-43.

Buurman, P., Pape, Th., Reijneveld, J. A., de Jong, R., and van Gelder, E., 2001: Laser-diffraction and pipette-method grain sizing of Dutch sediments: correlations for fine fractions of marine, fluvial, and loess samples. Geologie en Mijnbouw/Netherlands Journal of Geosciences, 80: 49-57.

Dahms, D. E., 1992: Comment on "Origin of Silt-Enriched Surface 
Mantles in Indian Basin, Wyoming." Soil Science Society of America Journal, 56: 991-992.

Dahms, D. E., 1993: Mineralogical evidence for eolian contribution to soils of late Quaternary moraines, Wind River Mountains, Wyoming, USA. Geoderma, 59: 175-196.

Dahms, D. E., and Rawlins, C. L., 1996: A two-year record of eolian sedimentation in the Wind River Range, Wyoming, U.S.A. Arctic and Alpine Research, 28: 210-216.

DiLabio, R. N. W., 1989: Terrain geochemistry in Canada. In Fulton, R. J. (ed.) Quaternary Geology of Canada and Greenland, Chapter 10. Geological Survey of Canada, Geology of Canada, 1: 645-663.

Dixon, J. C., 1991: Alpine and subalpine soil properties as paleoenvironmental indicators. Physical Geography, 12: 370-384.

Fall, P. L., 1997: Timberline fluctuations and late Quaternary paleoclimates in the Southern Rocky Mountains, Colorado. Geological Society of America Bulletin, 109: 1306-1320.

Gable, D. J., 1980: The Boulder Creek batholith, Front Range, Colorado. U.S. Geological Survey, Professional Paper, 1101: 88 pp.

Greenland, D., 1989: The climate of Niwot Ridge, Front Range, Colorado. Arctic and Alpine Research, 21: 380-391.

Haase, R., 1987: An alpine vegetation map of Caribou Lake Valley and Fourth of July Valley, Front Range, Colorado, U.S.A. Arctic and Alpine Research, 19: 1-10.

Hall, R. D., and Shroba, R. R., 1993: Soils developed in the glacial deposits of the type areas of the Pinedale and Bull Lake glaciations, Wind River Range, Wyoming, U.S.A. Arctic and Alpine Research, 25: $368-373$.

Hutton, J. T., 1977: Titanium and zirconium minerals. In Dixon, J. B., and Weed, S. B. (eds.), Minerals in Soil Environments. Madison, Wisconsin: Soil Science Society of America, 673-688.

Komárková, V., and Webber, P. J., 1978: An alpine vegetation map of Niwot Ridge, Colorado. Arctic and Alpine Research, 10: 1-29.

Konert, M., and Vandenberghe, J., 1997: Comparison of laser grain size analysis with pipette and sieve analysis: a solution for the underestimation of the clay fraction. Sedimentology, 44: 523-535.

Küfmann, C., 2003: Soil types and eolian dust in high-mountainous karst of the Northern Calcareous Alps (Zugspitzplatt, Wetterstein Mountains, Germany). Catena, 53: 211-227.

Lautridou, J. P., and Ozouf, J. C., 1982: Experimental frost shattering: 15 years of research at the Centre de Géomorphologie du CNRS. Progress in Physical Geography, 6: 215-232.

Lehmkuhl, F., Klinge, M., Rees-Jones, J., and Rhodes, E. J., 2000: Late Quaternary aeolian sedimentation in central and south-eastern Tibet. Quaternary International, 68-71: 117-132.

Litaor, M. I., 1987: The influence of eolian dust on the genesis of alpine soils in the Front Range, Colorado. Soil Science Society of America Journal, 51: 142-147.

Litaor, M. I., 1988: Reply to "Comments on 'The Influence of Eolian Dust on Alpine Soils." 'Soil Science Society of America Journal, 52: 301-302.

Lu, H., Vandenberghe, J., and An, Z., 2001: Aeolian origin and palaeoclimatic implications of the 'Red Clay' (north China) as evidenced by grain-size distribution. Journal of Quaternary Science, 16: 89-97.

Madole, R. F., 1986: Lake Devlin and Pinedale glacial history, Front Range, Colorado. Quaternary Research, 25: 43-54.

Madole, R. F., 1991a: Surficial geologic map of the Steamboat Springs $30^{\prime} \times 60^{\prime}$ Quadrangle, Grand, Jackson, and Routt Counties, Colorado. U.S. Geological Survey, Miscellaneous Investigations Series Map, I-1825: scale 1:100,000.

Madole, R. F., 1991b: Surficial geologic map of the Walden $30^{\prime} \times 60^{\prime}$ Quadrangle, Jackson, Larimer, and Routt Counties, Colorado. U.S. Geological Survey, Miscellaneous Investigations Series Map, I1824: scale 1:100,000.

Madole, R. F., VanSistine, D., and Michael, J. A., 1998: Glaciation in the upper Platte River drainage basin, Colorado. U.S. Geological Survey, Geologic Investigations Series, I-2644: scale 1:300,000.

Marr, J. W., 1964: The vegetation of the Boulder area. In Rodeck, H.G. (ed.), Natural History of the Boulder Area. University of Colorado Leaflet, 13: 34-42.

Marr, J. W., 1977: The development and movement of tree islands near the upper limit of tree growth in the Southern Rocky Mountains. Ecology, 58: 1159-1164.

Mason, J. A., Jacobs, P. M., Greene, R. S. B., and Nettleton, W. D., 2003: Sedimentary aggregates in the Peoria Loess of Nebraska, USA. Catena, 53: 377-397.

McLennan, S. M., 1989: Rare earth elements in sedimentary rocks: influence of provenance and sedimentary processes. Reviews in Mineralogy, 21: 169-200.

Meschede, M., 1986: A method of discriminating between different types of mid-ocean basalts and contrasting tholeiites with the $\mathrm{Nb}$ Zr-Y diagram. Chemical Geology, 56: 207-218.

Muhs, D. R., Aleinikoff, J. N., Stafford, T. W., Jr., Kihl, R., Been, J., Mahan, S. A., and Cowherd, S., 1999: Late Quaternary loess in northeastern Colorado: Part I-age and paleoclimatic significance. Geological Society of America Bulletin, 111: 1861-1875.

Muhs, D. R., Bettis, E. A., III, Been, J., and McGeehin, J., 2001: Impact of climate and parent material on chemical weathering in loess-derived soils of the Mississippi River Valley. Soil Science Society of America Journal, 65: 1761-1777.

Muhs, D. R., Ager, T. A., Bettis, E. A., III, McGeehin, J., Been, J. M., Begét, J. E., Pavich, M. J., Stafford, T. W., Jr., and Stevens, D. S. P., 2003: Stratigraphy and paleoclimatic significance of late Quaternary loess-paleosol sequences of the last interglacial-glacial cycle in central Alaska. Quaternary Science Reviews, 22: 1947-1986.

Muhs, D. R., McGeehin, J. P., Beann, J., and Fisher, E., 2004: Holocene loess deposition and soil formation as competing processes, Matanuska Valley, southern Alaska. Quaternary Research, 61: 265-276.

Munn, L. C., 1988: Comments on "The Influence of Eolian Dust on Alpine Soils." Soil Science Society of America Journal, 52: 301.

Munn, L. C., 1992: Response to "Comments on 'Origin of SiltEnriched Surface Mantles in Indian Basin, Wyoming." Soil Science Society of America Journal, 56: 992-993.

Munn, L. C., and Spackman, L. K., 1990: Origin of silt-enriched alpine surface mantles in Indian Basin, Wyoming. Soil Science Society of America Journal, 54: 1670-1677.

Nelson, A. R., Millington, A. C., Andrews, J. T., and Nichols, H., 1979: Radiocarbon-dated upper Pleistocene glacial sequence, Fraser Valley, Colorado Front Range. Geology, 7: 410-414.

Pearce, J. A., and Cann, J. R., 1973: Tectonic setting of basic volcanic rocks determined using trace element analyses. Earth and Planetary Science Letters, 19: 290-300.

Pearson, R. C., 1980:Mineral resources of the Indian Peaks study area, Boulder and Grand Counties, Colorado: U.S. Geological Survey, Bulletin, 1463: 109 pp.

Reheis, M. C., 2003: Dust deposition in Nevada, California, and Utah, 1984-2002. U.S. Geological Survey, Open-File Report, 03-138: version 1.0 (http://pubs.usgs.gov/of/2003/ofr-03-138/).

Reheis, M. C., Budahn, J. R., and Lamothe, P. J., 2002: Geochemical evidence for diversity of dust sources in the southwestern United States. Geochimica et Cosmochimica Acta, 66: $1569-1587$.

Rieger, S., 1983: The genesis and classification of cold soils. New York, Academic Press, 230 pp.

Rost, K. T., 2001: Late Holocene loess deposits and dust accumulation in the alpine meadow belt of the Wutai Shan, China. Quaternary International, 76/77: 85-92.

Shaver, G. R., and Chapin, F. S., III, 1986: Effect of fertilizer on production and biomass of tussock tundra, Alaska, U.S.A. Arctic and Alpine Research, 18: 261-268.

Shroba, R. R., and Birkeland, P. W., 1983: Trends in late-Quaternary soil development in the Rocky Mountains and Sierra Nevada of the western United States. In Porter, S. C. (ed.), Late-Quaternary environments of the United States, Volume 1, The late Pleistocene. Minneapolis: University of Minnesota Press, 145-156.

Sneddon, J. I., Lavkulich, L. M., and Farstad, L., 1972: The morphology and genesis of some alpine soils in British Columbia, Canada: II. Physical, chemical, and mineralogical determinations and genesis. Soil Science Society of America Proceedings, 36: 104-110.

Taylor, S. R., and McLennan, S. M., 1985: The Continental Crust: Its 
Composition and Evolution. Oxford: Blackwell Scientific Publications, $312 \mathrm{pp}$.

Theodose, T. A., and Bowman, W. D., 1997: Nutrient availability, plant abundance, and species diversity in two alpine tundra communities. Ecology, 78: 1861-1872.

Thorn, C. E., 1979: Bedrock freeze-thaw weathering regime in an alpine environment, Colorado Front Range. Earth Surface Processes, 4: 211-228.

Thorn, C. E., and Darmody, R. G., 1980: Contemporary eolian sediments in the alpine zone, Colorado Front Range. Physical Geography, 1: 162-171.

Thorn, C. E., and Darmody, R. G., 1985: Grain-size distribution of the insoluble component of contemporary eolian deposits in the alpine zone, Front Range, Colorado, U.S.A. Arctic and Alpine Research, 17: 433-442.

Wang, X., Dong, Z., Zhang, J., and Zhao, A., 2002: Relations between morphology, air flow, sand flux and particle size on transverse dunes, Taklimakan Sand Sea, China. Earth Surface Processes and Landforms, 27: 515-526.

Wright, J., 2001: Making loess-sized quartz silt: data from laboratory simulations and implications for sediment transport pathways and the formation of 'desert' loess deposits associated with the Sahara. Quaternary International, 76/77: 7-19.

Wright, J., Smith, B. J., and Whalley, W. B., 1998: Mechanisms of loess-sized quartz silt production and their relative effectiveness: laboratory simulations. Geomorphology, 23: 15-34.

Young, E. J., 1991: Geologic map of the East Portal quadrangle, Boulder, Gilpin, and Grand Counties, Colorado. U.S. Geological Survey, Miscellaneous Investigations Series Map, I-2212: scale 1:24,000.

Zeuner, F. E., 1949: Frost soils on Mount Kenya and the relation of frost soils to aeolian deposits. Journal of Soil Science, 1: 20-30.

Revised ms submitted June 2005 